\title{
Assessment of Ecological Water Discharge from Volgograd Dam in the Volga River Downstream Area, Russia
}

\author{
I. P. Aidarov ${ }^{1}$, Yu. N. Nikolskii ${ }^{2}$ \& C. Landeros-Sánchez ${ }^{3}$ \\ ${ }^{1}$ Russian Academy of Sciences, Russia \\ ${ }^{2}$ Colegio de Postgraduados, Campus Montecillo, Mexico \\ ${ }^{3}$ Colegio de Postgraduados, Campus Veracruz, Mexico \\ Correspondence: C. Landeros-Sánchez, Colegio de Postgraduados, Campus Veracruz, km 88.5 Carretera Federal \\ Xalapa-Veracruz, vía Paso de Ovejas, entre Puente Jula y Paso San Juan, Tepetates, Veracruz, C.P. 91690, México. \\ Tel: 229-201-0770. E-mail: clandero@colpos.mx
}

Received: October 18, 2017

Accepted: November 20, 2017 Online Published: December 15, 2017

doi:10.5539/jas.v10n1p56

URL: https://doi.org/10.5539/jas.v10n1p56

\begin{abstract}
Water release from reservoirs to improve the environmental condition of floodplains is of great relevance. Thus, the aim of this study was to propose a method to assess ecological drawdowns from power station reservoirs. An example of its application for the Volga River downstream area is presented. The efficiency of the quantitative assessment of ecological water discharge from the reservoir of the Volgograd hydroelectric power station is analyzed and discussed in relation to the improvement of the environmental condition of the Volga-Akhtuba floodplain, which covers an area of $6.1 \times 10^{3} \mathrm{~km}^{2}$. It is shown that a decrease of spring-summer flooding worsened significantly its environmental condition, i.e. biodiversity decreased by 2-3 times, soil fertility declined by $25 \%$, floodplain relief deformation occurred and the productivity of semi-migratory fish decreased by more than 3 times. The economic benefit accumulated from river flow regulation was $\approx 300 \times 10^{6}$ USD in 2011 , and economic damage related to the deterioration of the ecological situation was estimated at $\approx 400 \times 10^{6}$ USD in the same year. It is impossible to fully satisfy the needs of all the participants in the water-economic complex in the assessment of the environmental flows. Priority should be given to environmental requirements. It was found that assessing the ecological drawdowns confirmed the possibility of improving the floodplain environment by reducing between $15-20 \%$ the electricity production. This would allow conserving the region's biodiversity and increasing about $60-80 \%$ the natural vegetation productivity. This will prevent deformation of the floodplain relief and doubling the productivity of semi-migratory fish.
\end{abstract}

Keywords: mathematical models, ecological drawdowns, dam realese, environmental improvement, floodplain sustainability

\section{Introduction}

The possibility of multi-purpose use of water resources by means of river flow regulation was long considered to be sign of scientific and technical progress and humankind's ability to manage natural resources. However, by the end of the 20th century, it had become clear that the long-term flow regulation of lowland rivers in Russia had both positive impact on the economy and negative impact on the environment and living conditions of human beings (Aidarov, Venitsianov, \& Radkovich, 2002).

The regulation of lowland river flow in Russia in the 20th century was primarily aimed at increasing the amount of available water resources by means of equalizing the uneven flow in seasons and years with different dryness, i.e. by means of accumulating water during floods and using it in other periods of the year. Unfortunately, such a change in the natural flow regime harmed the natural environment below the dams, resulting in the following negative impacts (Iolin, Sorokin, \& Starichkova, 2011; Loginov \& Gelashvili, 2016):

$>$ Loss of part of the river runoff due to increased evaporation from the surface of the constructed reservoirs;

> Blockage of natural fish migration routes by dams;

> Modification of water exchange, temperature and quality in the reservoirs;

$>$ Reduction of sediment and nutrient river runoff, along with deterioration of channel processes; 


\section{$>$ Deformation of floodplain relief;}

$>$ Degradation of terrestrial and aquatic ecosystems and reduction of their bio-productivity;

$>$ Deterioration of the elements of river systems (deltas, lakes, etc.).

In addition, the construction of reservoirs on lowland rivers was accompanied by the loss of large tracts of land valuable for agricultural and other uses and resettlement of people from the flooded areas.

These adverse impacts of river flow regulation have been documented in the USA, China, Sweden and some other countries as well (Zhong \& Power, 1996; Tockner \& Stanford, 2002). The World Commission on Dams (WCD) notes that in many cases, despite the positive effect, the main economic and technical aims of river flow regulation are not achieved because of the negative impacts; the ecological damage is comparable to, or even greater than the effect of the multiple uses of water resources (White, 1989; WCD, 2000). It should be also mentioned that managing multi-purpose reservoirs is a complex task because water users present their own unique demands in terms of the volume, regime and quality of the river flow. For example, the hydropower and water transport industries require maximum flood flow regulation, and agriculture, fishery, and the public require maximum conservation of the natural mode of water and solid runoff and natural water quality.

Therefore, the main goal of the environmental water releases from the dams should be to reduce the possible negative ecological impact of flow regulation and to improve the environment condition. In the case of floodplain ecosystem conservation, it is necessary to strive for preservation of the natural flood regime in certain periods of the year and for maximum possible conservation of water in the reservoir during remaining periods by means of better water-use efficiency by the different users involved.

In assessing ecological water releases from the dam of a lowland river, it is necessary to consider the following points (Aidarov, Venitsianov, \& Radkovich, 2002; Ratkovich, 2003):

It is impossible to return the environment to its natural state, but it is possible to restore (improve) the environment to a level at which the stable functioning of an ecosystem will be ensured, according to the Le Chatelier-Braun principle (Palmeri, Barausse, \& Jorgensen, 2014).

$>$ However, by changing the flow of the regulated river, it is possible to improve the ecological condition of the river and adjacent floodplains below the dam, but this condition will be still different from the natural one.

$>$ In modifying the exited regulated river flow, it is necessary to consider not only individual components of the environment but the entire ecosystem as a whole.

> The basic approaches to assessing ecological drawdowns from reservoirs, constructed for electricity production or/and irrigation needs or other civil purposes, are based on the following:

$>$ Economic analysis of the possibility of modifying the hydrograph of the regulated river so that it is closer to the natural hydrograph before regulation (Richter \& Thomas, 2007; Warner, Bach, \& Hickey,2014).

$>$ Use of empirical relationships between separate interlinked environmental factors and a regime of the regulated river flow (Shevtsova, Aliev, \& Kuzko, 1998; Nikitina, 2015).

Technically it can be achieved by different ways:

> Modifying the drawdown regime and that of the hydroelectric stations;

$>$ Reducing water demand by means of better efficiency of water transport from dams and better application in irrigated lands or use in populated localities;

$>$ In some cases, removing or replacing levees along the river below the dam.

In this paper, a method of assessing ecological water releases from the dam, based on a comprehensive analysis of the relationship between the reservoir functioning and the environmental conditions is proposed. An example of its application for the Volga River region downstream of the Volgograd dam is presented.

\section{Material and Methods}

The Volga-Akhtuba floodplain covers an area of $6.1 \times 10^{3} \mathrm{~km}^{2}$ along the Volga River in Russia, which is located downstream of the Volgograd hydroelectric power station (Figure 1). The lowland Volga River is the longest in Europe, with a length of $3,530 \mathrm{~km}$ and a catchment area of $1.36 \times 10^{6} \mathrm{~km}^{2}$.

The mean annual flow of the Volga River in the alignment of the Volgograd hydroelectric power station is 239 $\mathrm{km}^{3}$. The intra-annual distribution of the flow under natural conditions was as follows: the spring-summer flood, $66 \%$; the summer-autumn low water, 21\%; the winter low flow, 13\% (Gidroproyect, 1955; Ratkovich, 2003). 


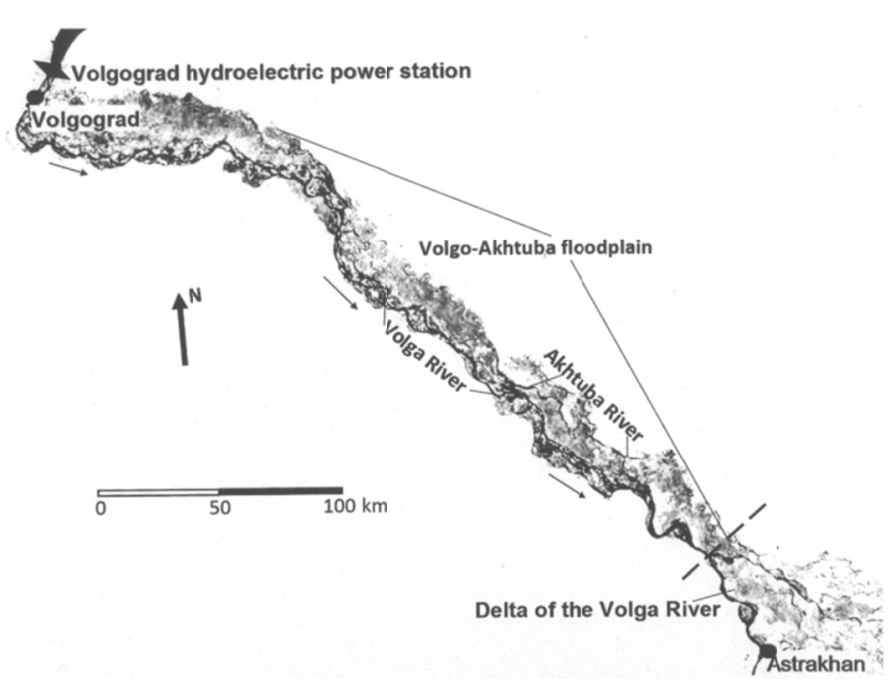

Figure 1. Map location of Volgograd hydroelectric power station and Volga-Akhtuba floodplain in Russia. Volgograd and Astrakhan are cities with a population of about $1 \times 10^{6}$ residents

As a result of river regulation, the intra-annual distribution of river flow has changed significantly and it is now the following: the spring-summer flood, $39 \%$; the summer-autumn low water, $34 \%$; the winter low flow, $27 \%$ (Gidroproyect, 1955; Ratkovich, 2003).

The natural ecological system of the Volga-Akhtuba floodplain was initially formed under the influence of zonal and azonal habitat-forming factors. The former include solar energy and precipitation, whereas the latter relate to delivery of large volumes of water and sediments during the spring-summer floods, periodically causing formation of the floodplain under aquatic or aerial conditions. This circumstance has played an important role not only in the formation of the biodiversity of its herbaceous, shrubby and arboreal vegetation, including a number of endemic species such as Sphaeranthus volgensis, Tzvel Ceratophyllum kossinskyi, Kuzen Melandrium astrachanicum Pacz, etc., but also in the sustainability of the floodplain ecosystem as a whole. It is known that biodiversity and ecosystem sustainability increase with increasing variation of habitat-forming factors and with improved water and thermal conditions in the territory (Ramenskiy, Tsatsenkin, \& Chizhikov, 1954; Aidarov, Venitsianov, \& Radkovich, 2002).

For a quantitative estimation of the future state of the environment, it is possible to use general long-term prediction models existing in the bibliography. Herein, it was used a system of simulation models describing the dynamics of the environmental conditions of floodplains, such as their biodiversity, natural vegetation productivity, land use, erosion, soils quality, fish productivity, and ecological sustainability of their ecosystems as a whole, depending on the main habitat-forming factors.

The following model was used to describe the dynamics of natural vegetation biodiversity (Odum, 1983; Riznichenko, 2010):

$$
B_{i+1}=B_{i}\left[\mathrm{r}\left(1-\frac{B_{i}}{B_{\max }}\right)\right]
$$

Where, $B_{i}$ and $B_{i+1}$ represent the natural vegetation biodiversity in the years $i$ and $i+1$ under modified conditions as a fraction of the biodiversity under natural conditions; $r$ is a constant characterizing the biological characteristics of the vegetation (dimensionless) and varying between 0 and $1: r=1$ for natural vegetation and $r$ $=0$ in case of absence of vegetation; $B_{\max }$ is the capacity of ecological niches of vegetation populations (dimensionless), $B_{\max }$ values were determined by means of data by Ramenskiy et al. (1954), depending on: the radiative index of dryness of the floodplain $I$ and the amount of incoming suspended sediments, organic and biogenic substances together with the river solid runoff during the spring-summer floods (Ramenskiy, Tsatsenkin, \& Chizhikov, 1954; Barmin, Iolin, \& Grigorenkova, 2012).

The $I$ index was calculated as follows (Aidarov \& Zavalin, 2015):

$$
I=\frac{R}{L(P r+W)}
$$


Where, $I$ is dimensionless; $R$ is the mean annual net radiation $\left(\mathrm{Kj} / \mathrm{cm}^{2} /\right.$ year $) ; L$ is the latent heat of evaporation $\left(2.51 \mathrm{Kj} / \mathrm{cm}^{3}\right) ; \operatorname{Pr}$ and $W$ are the mean annual amounts of water coming to the floodplain, i.e., precipitation and annual drawdown from the reservoir during the spring-summer floods ( $\mathrm{cm} /$ year).

The sustainability of the Volga-Akhtuba floodplain ecosystem $\left(K_{S}\right)$ was estimated using the following expression (Odum, 1983; Chernikov \& Cherekes, 2000):

$$
K_{S}=\sum_{i=1}^{\mathrm{n}} \frac{A_{i}}{A_{0}} K_{i} K_{0}
$$

Where, $K_{S}$ is a dimensionless parameter of the ecosystem sustainability varying between 0 and $1: K_{S}<0.33$ means unstable ecosystem; 0.34-0.50, weak-stable; 0.51-0.66, mid-stable; 0.67-1.0, stable; $n$ is the number of biotic and abiotic components of the ecosystem; $A_{i} / A_{0}, A_{i}$ is the area of each biotic and abiotic component of the ecosystem as a fraction of total area of the ecosystem $\left(A_{0}\right) ; K_{i}$ is a dimensionless factor of relative ecological significance of each component of the ecosystem, varying between 0 and $1 ; K_{0}$ is a dimensionless factor of geological and geomorphological sustainability of the floodplain surface, varying between 0 and 1 .

The values of $K_{i}$ were taken from Table 1 . The values of $K_{0}$ were estimated depending on the degree of erodability of the floodplain during the spring-summer floods. Using the reported data (Baryshnikov, 1984; Barmin et al., 2012), empirical formulae were proposed to estimate the intensity of water erosion of the Volga-Akhtuba floodplain $(E r)$ depending on the parameter of its projective surface coverage $(\beta)$ and on the parameter of delivery of suspended sediments during the spring-summer floods $(\delta)$ :

$$
\operatorname{Er}=\exp (-\beta \delta)
$$

(For surface slopes less than 0.005 typical for the floodplain)

Where, $E r$ is expressed in t/ha/year.

$$
\begin{gathered}
\beta=1-\exp (-0.04 B) \\
\delta=\lambda\left(W_{\text {spr }} / W_{\text {annual }}\right)
\end{gathered}
$$

$\beta, \delta$ and $B$ are dimensionless parameters varying between 0 and $1 ; B$ is the natural vegetation biodiversity of the floodplain in modern conditions expressed as a fraction of the biodiversity under natural conditions before construction of the Volgograd hydroelectric power station; $W_{s p r}$ and $W_{\text {annual }}$ are the volumes of drawdowns during spring-summer period and the annual one, respectively $\left(\mathrm{km}^{3}\right) ; \lambda$ is a dimensionless parameter and varies basically between 1.4 and 2.2. The parameter of projective surface coverage $(\beta)$ reflects the degree of the floodplain coverage with the natural vegetation. Making use of data published by Chernikov and Cherekes (2000), and Korotaev and Ivanov (2000) and calculated values of $E r$, an average value of $K_{0}=0.7$ was obtained.

Table 1. $K_{i}$ values for the biotic and abiotic components of landscapes (as well as of floodplains) under natural semi-humid and semi-arid climatic conditions

\begin{tabular}{ll}
\hline Biotic and abiotic components & $K_{i}$ values \\
\hline Water bodies & 1.00 \\
Forest vegetation & 0.90 \\
Grasslands and pastures & 0.93 \\
Rainfed arable lands & 0.10 \\
Irrigated arable lands & 0.25 \\
Limans (depressions filled with water during floods or lakes of the floodplain) & 0.82 \\
Sandy lands & 0.00 \\
Industrial and civil objects & -1.00 \\
\hline
\end{tabular}

Note. a) Semi-humid and semi-arid climatic conditions are characterized by means of climatic index $I$, calculated with formalue (2) where $W=0$, when $1 \leq I<2.5$; and b) In case of the Volga-Akhtuba floodplain, $K_{i}$ values for the natural conditions characterize conditions existing before 1940 when construction began on the reservoirs in the Volga River Basin.

Soil quality was assessed by means of the integral index of soil fertility $(F)$ in the $0-20 \mathrm{~cm}$ soil layer (Pegov \& Khomyakov, 1991):

$$
\mathrm{F}=0.011\left(\mathrm{OM}_{\mathrm{h}}+0.2 \cdot \mathrm{OM}_{\mathrm{f}}\right)+8.5 \sqrt[3]{\mathrm{NPK}}+5.1 \exp \left(-\frac{|\mathrm{H}-1|}{4}\right)
$$


Where, $F$ is dimensionless and varies between 0 and 1 ( 1 corresponds to the best soil quality and 0 to completely degraded soil); 0.011 is a normalizing factor (ha/t); $O M_{h}$ and $O M_{f}$ are the contents of humic and fulvic forms of organic matter, respectively ( $\mathrm{t} / \mathrm{ha}) ; N, P$ and $K$ are dimensionless contents of available nutrients for plants as a fraction of their possibly maximal content of $N, P$ and $K$ (varying between 0 and 1 ); $H$ is the hydrolytic acidity of soil $(\mathrm{cmol} / \mathrm{kg})$; the denominator 4 is a normalizing factor $(\mathrm{cmol} / \mathrm{kg})$.

The quality of surface water was assessed by the dimensionless water pollution index $(W P)$, taking into account the main pollutants (Ratkovich, 2003):

$$
W P=\frac{1}{m} \sum_{j=1}^{m} \frac{C_{j}}{C_{j}^{p e r m}}
$$

Where, $m$ is the total number of main pollutants; $C_{j}$ and $C_{j}^{\text {perm }}$ are their concentrations and permissible levels, respectively.

Since it is more difficult to assess fish reproduction, the regulation of river flow resulted in the reduction of more than $90 \%$ of the natural spawning grounds of migratory fish. This has led to a catastrophic reduction in fish productivity. In modern conditions, the main concern is the preservation of migratory fish as individual species rather than as an object of the fishing industry.

As for semi-migratory fish, a mode and quality of liquid and solid river flow and condition of spawning grounds within the floodplain play the main role in formation of fish productivity. Analysis of long-term data (Ratkovich, 2003; Zvolinskiy, 2016) allowed us to obtain the dependence of semi-migratory fish production $(P)$ on duration of floodplain flooding $\left(t_{f l}\right)$ and condition of spawning grounds as expressed by means of the parameter of projective surface coverage $(\beta)$ :

$$
P=40 \beta \exp \left(\gamma_{f l}\right)
$$

Where, $P$ is the fish production in thousands of tons per year; $\gamma$ is a dimensionless parameter taking into account the effect of temperature and quality of water during the spring-summer flooding, on average $\gamma=0.07 ; \beta$ is a parameter expressed by Equation (5); $t_{f l}$ is expressed in days and assessed depending on the volume of the spring-summer drawdown as a fraction of annual river flow, which varies between 25 and 40 days approximately.

It should be noted that the annual fish production data do not represent the general trend in several years. Periods of not less than 5 years should be considered for assessment of fish production (Ratkovich, 2003).

In order to apply the above-mentioned models to assess ecological water release from the Volgograd dam, it is necessary, first of all, to verify their applicability to assess the dynamics of natural processes. For this, it was made use of the results of long-term observations of liquid and solid flows of the Volga River in the alignment of the Volgograd hydroelectric power station, as well as the results of long-term studies on the environmental state under natural conditions (from 1881 until 1941) and under river flow regulation conditions (from 1981 until 2010). Existing data characterize the natural (in the past) and modern state of the floodplain (Plyusnin, 1938; Iolin, Sorokin, \& Starichkova, 2011).

\section{Results and Discussions}

Using the described above models, various environmental parameters of the Volgo-Akhtuba floodplane and its sustainability were calculated. The calculated values were compared with parameters based on the real observations. This allowed assessing the acceptability of this approach so as to justify recommendations for regulating ecological water discharge from Volgograd dam in the Volga river downstream area.

Tables 2 and 3 present results of comparison between actual and calculated environmental parameters of the Volga-Akhtuba floodplain and its environmental sustainability. 
Table 2. The comparison between calculated and observed data on the environmental conditions of the Volga-Akhtuba floodplain

\begin{tabular}{lll}
\hline \multirow{2}{*}{ Indicators } & \multicolumn{2}{c}{ Values of indicators } \\
\cline { 2 - 3 } & Calculated & Observed \\
\hline Biodiversity of the natural vegetation (dimensionless) & $0.98 / 0.46$ & $1.00 / 0.40$ \\
Bioproductivity of the natural vegetation (t/ha/year) & $28 / 10$ & $30 /(6-8)$ \\
Parameter $\beta$ of the projective surface coverage (dimensionless) & $0.97 / 0.85$ & $1.00 / 0.80$ \\
Soil erosion (t/ha/year) & $0.42 / 0.57$ & $0.52 / 0.59$ \\
Delivery of sediments during spring-summer floods (t/ha/year) & $1.50 / 0.51$ & $1.52 / 0.51$ \\
Delivery of sediments minus soil erosion (t/ha/year) & $1.08 /-0.06$ & $1.00 /-0.01$ \\
Integral index of soil fertility (dimensionless) & $1.00 / 0.75$ & $1.00 /(0.60-0.70)$ \\
Fish productivity (thousand of tons per year) & $1100 / 330$ & $950 / 290$ \\
\hline
\end{tabular}

Note. The numbers in the numerator correspond to the natural conditions and those in the denominator to modern ones.

Table 3. The assessment of the parameter of environmental sustainability $K_{S}$ of the Volga-Akhtuba floodplain by Equation (3)

\begin{tabular}{llll}
\hline Components of the floodplain ecosystem & $A_{i} / A_{0}$ & $K_{i}$ & $\left(A_{i} / A_{0}\right) K_{i} K_{0}$ \\
\hline Surface of Volga and Akhtuba Rivers ${ }^{*}$ & $0.20 / 0.20$ & $1 / 0.56$ & $0.14 / 0.078$ \\
Forests & $0.15 / 0.131$ & $0.9 / 0.9$ & $0.094 / 0.083$ \\
Meadows and pastures & $0.586 / 0.521$ & $0.93 / 0.31$ & $0.381 / 0.113$ \\
Limans and Eriks ${ }^{* *}$ & $0.029 / 0.057$ & $0.82 / 0.75$ & $0.016 / 0.030$ \\
Sandy lands & $0.035 / 0.035$ & $0 / 0$ & $0 / 0$ \\
Irrigated arable lands & $0 / 0.043$ & $0 / 0.25$ & $0 / 0.008$ \\
Rainfed arable lands & $0 / 0.006$ & $0 / 0,10$ & $0 / 0.0004$ \\
Industrial and civil objects & $0 / 0.006$ & $0 /-1$ & $0 /-0.001$ \\
Parameter $K_{S}$ of ecosystem sustainability & & & $0.631 / 0.311$ \\
\hline
\end{tabular}

Note. The numbers in the numerator correspond to the natural conditions and those in the denominator to modern ones; "Surface of Volga and Akhtuba Rivers corresponds to mean annual water surface of these rivers considering flood and low water periods; ${ }^{* *}$ Limans and Eriks are local names respectively of small lakes and rivers inside the floodplain.

The calculations were made by the above-described models for natural conditions, which existed before 1940 , that is, before construction of the Volgograd hydroelectric power station when the mean annual flow of the spring-summer flood was $158 \mathrm{~km}^{3}$ and for modern conditions, when the hydrological regime of the Volga River has been changed and the mean annual flow of the spring-summer flood is $94 \mathrm{~km}^{3}$.

The calculations show that the used models allow to quantitatively assessing the direction of the environmental change under the influence of the modified hydrological regime of the Volga River. These models also assess the intensity of the degradation processes, such as: change in the biodiversity and productivity of natural vegetation, in soil fertility, relief and environmental sustainability of the Volga-Akhtuba floodplain. Probably, a similar approach based on the use of general models (1), (2), (3), (7) and (8) could be applied to assess the river flow regulation in some other regions. However, in each specific case it should be necessary to establish the empirical requirements (4), (9) for the specific local conditions.

The obtained results led to draw some important practical conclusions:

(1) Natural fluctuations in flow regime do not lead to a disruption of long-term environmental functioning of the floodplain. On the contrary, these fluctuations play an important role as a historically formed floodplain ecosystem; such fluctuations were well adapted to the natural river flow regime. In this regard, it is not necessary to demand equal volumes of spring-summer floods in the years with different dryness.

(2) The floodplain ecosystem under natural conditions was characterized by average sustainability $\left(K_{S}=0.631\right)$, which means the average long-term stability of all components of the environment. 
(3) A decrease in the volume of the spring-summer floods and a change in the natural flood regime disturbed the steady state of the floodplain ecosystem and significantly worsened the condition of all its components, including:

$>$ Reduction in biodiversity of natural vegetation and simplification of its species composition. The biodiversity and productivity of the natural vegetation has decreased by more than 2-3 times. Xerophytic vegetation began to dominate in the structure of the species composition.

$>$ Reduction in soil fertility. The integrated index of soil fertility has decreased by $25 \%$ : from 1.00 to 0.75 .

$>$ Increased erosion of floodplain soils and disturbance of the sediment balance, which have caused deformation of the floodplain relief.

$>$ Decrease in productivity of semi-migratory fish by more than 3 times.

$>$ Inevitability of further degradation processes in the Volgo-Ahtuba floodplain if the existing river flow regime is maintained. The parameter of its present environmental sustainability $\left(K_{S}\right)$ is reduced two times: from 0.631 to 0.311 . It means that now the floodplain ecosystem is unstable.

(4) In general, the presented models could be used for assessing ecological releases from the Volgograd dam. Some discrepancies between the calculated and observed data seem mainly related to a lack of information on the state of the floodplain environment.

(5) The river flow regulation caused not only deterioration in the floodplain environment, but also in the efficiency of natural resource use. The economic benefit of the river flow regulation was approximately $300 \times$ $10^{6}$ USD in 2011, but the assessed economic damage related to negative ecological impacts was about $400 \times 10^{6}$ USD. This general assessment of the efficiency of the river flow regulation corresponds to the conclusions of the World Commission on Dams (WCD, 2000).

Considering the obtained results in the assessment of ecological releases from the Volgograd dam, it is necessary to take into account the following:

$>$ It is impossible to fully satisfy the requirements of all the water complex users, and priority should be given to the ecological requirements.

$>\quad$ It is necessary to improve the condition of the Volga-Akhtuba floodplain ecosystem to a level at which its sustainability would be restored and its further degradation would be prevented.

$>\quad$ It is unacceptable banking of the floodplain and its use for growing highly productive agricultural crops. Such crops are not able to normalize environmental conditions and prevent land degradation. Irrigation is possible only within the non-flooded upper part of the floodplain.

$>$ It is advisable to increase the spring-summer floods by slightly reducing power generation, i.e. reducing the turbine flow during the summer-autumn and winter seasons. The resulting relatively small power deficit could be offset by increasing production at existing thermal and other power plants.

$>$ It is necessary to change the existing rules for using the cascade of all Volga reservoirs.

$>$ Predictions of change in the ecological condition because of river flow regulation should be carried out for periods of not less than 30 years.

In order to assess long-term change in the environmental condition of the floodplain, actual data on the Volga River flow in the alignment of the Volgograd hydroelectric power station from 1980 to 2010 must be used, considering the expected irretrievable water consumption in the Volga River basin in 2020.

Five potential options for the river flow regulation were considered:

$>$ Conservation of modern spring-summer drawdown without a reduction in power generation.

$>$ Reduction of power generation by $5 \%$ of the modern level.

$>$ Reduction of power generation by $10 \%$ of the modern level.

$>$ Reduction of power generation by $15 \%$ of the modern level.

$>$ Reduction of power generation by $20 \%$ of the modern level.

The calculations took into account the volumes of the spring-summer flow, duration of the floodplain flood, and reduction of solid and biogenous river flow. The mean annual spring-summer flood flow in the calculations did not exceed $64-83 \%$ of the level existing under natural conditions before regulation of the river flow. However, it should be noted that in the calculation, nonuniformity of river flood flows in different years was conserved. 
Some activities have been also considered for improving the quality of water resource and the structure of floodplain land use (Voronina, 2009; Government of the Astrakhan region, 2010).

The results of long-term predictions of the ecological state of the Volga-Akhtuba floodplain corresponding to each option are presented in Tables 4 and 5.

Table 4. Results of long-term predictions on the ecological condition of the Volga-Akhtuba floodplain

\begin{tabular}{llllll}
\hline \multirow{2}{*}{ Indicators } & \multicolumn{4}{c}{ Values of indicators according to the options } \\
\cline { 2 - 6 } & 1 & 2 & 3 & 4 & 5 \\
\hline Mean annual volume of the spring-summer flood flow (km (kear) $^{3}$ ) & 94 & 100 & 106 & 114 & 120 \\
Biodiversity of natural vegetation (dimensionless) & 0.38 & 0.48 & 0.51 & 0.60 & 0.66 \\
Bioproductivity of natural vegetation (t/ha/year) & 10 & 11 & 13 & 15 & 17 \\
Parameter $\beta$ of the projective surface coverage (dimensionless) & 0.54 & 0.60 & 0.82 & 0.88 & 0.90 \\
Soil erosion (t/ha/year) & 0.62 & 0.59 & 0.49 & 0.45 & 0.44 \\
Delivery of sediments during spring-summer floods (t/ha/year) & 0.50 & 0.53 & 0.56 & 0.61 & 0.64 \\
Delivery of sediments minus soil erosion (t/ha/year) & -0.12 & -0.06 & 0.07 & 0.16 & 0.20 \\
Integral index of soil fertility (dimensionless) & 0.74 & 0.76 & 0.77 & 0.79 & 0.80 \\
Fish productivity (thousand of tons per year) & 250 & 300 & 400 & 500 & 600 \\
\hline
\end{tabular}

As for migratory fish (sturgeon, stellate sturgeon and beluga), it is necessary to note that at a mean annual ecological drawdown equal to $120 \mathrm{~km}^{3}$ and the stability condition of the Caspian Sea level, it is possible to save only the sturgeon species (Yakovlev, 2014).

As can be seen, even a slight increase of $6 \%$ in the volume of the spring-summer drawdown can lead to an improvement in the ecological situation of the Volga-Akhtuba floodplain. In this case, it is possible to increase biodiversity and natural vegetation productivity, reduce soil erosion, improve soil quality, increase productivity of semi-migratory fish and enhance the environmental sustainability of the floodplain. The expected reduction in power generation will be only $5 \%$.

The most significant effect among the considered options is expected with an increase in the volume of the spring-summer drawdown by $26 \%$. In this case, the reduction in power generation will be $20 \%$, which, apparently, can be compensated by increasing production at existing thermal and other power plants.

It should be noted that in Table 5, unlike in Table 3, two ecosystem components, namely rainfed arable lands and industrial and civil objects, are absent. This is because present Russian Federal legislation stipulates that all periodically flooded floodplains can be used in rainfed agriculture such as meadows and pastures. Irrigation is only permitted in floodplain areas not subject to flooding.

Table 5. Assessment of the parameter of environmental sustainability $K_{S}$ of the Volga-Akhtuba floodplain by Equation (3)

\begin{tabular}{lllllll}
\hline \multirow{2}{*}{ Components of the floodplain ecosystem } & \multirow{2}{*}{$A_{i} / A_{0}$} & \multicolumn{5}{c}{$\left(A_{i} / A_{0}\right) K_{i} K_{0}$ values according to the options } \\
\cline { 3 - 7 } & & 1 & 2 & 3 & 4 & 5 \\
\hline Surface of Volga and Akhtuba Rivers & 0.20 & 0.086 & 0.086 & 0.086 & 0.086 & 0.086 \\
Forests & 0.131 & 0.083 & 0.083 & 0.083 & 0.083 & 0.083 \\
Meadows and pastures & 0.414 & 0.090 & 0.093 & 0.107 & 0.133 & 0.156 \\
Limans and Eriks & 0.057 & 0.030 & 0.030 & 0.030 & 0.030 & 0.030 \\
Sandy lands & 0.036 & 0 & 0 & 0 & 0 & 0 \\
Irrigated arable lands & 0.162 & 0.028 & 0.028 & 0.028 & 0.028 & 0.028 \\
Parameter $K_{S}$ of ecosystem sustainability & 1.0 & 0.317 & 0.320 & 0.334 & 0.360 & 0.383 \\
\hline
\end{tabular}

Note. ${ }^{*}$ Surface of Volga and Akhtuba Rivers corresponds to mean annual water surface of these rivers considering flood and low water periods; ${ }^{* *}$ Limans and Eriks are local names respectively of small lakes and small rivers inside the floodplain. 


\section{Conclusions}

The results of long-term predictions confirmed the possibility of improving the ecological condition of the Volga-Akhtuba floodplain. By reducing power generation by 15 to $20 \%$, it is possible to increase the environmental sustainability of the floodplain to a permissible level, improve the state of natural resources, and increase the efficiency of their use. The parameter of environmental sustainability of the floodplain $K_{S}$ can be increased from 0.360 to 0.383 , which ensures conservation of biodiversity and natural vegetation productivity. Soil fertility can be increased up to 60 or $80 \%$ of the natural state, so as to prevent deformation of the floodplain relief. The productivity of semi-migratory fish can be increased twofold.

Further improvement of the Volga-Akhtuba floodplain requires consideration of Volga River basin, as well as the Caspian Sea basin. This affects the interests of many regions of Russia and other countries, which significantly complicates the situation.

\section{Acknowledgements}

To Colegio de Postgraduados (Campus Montecillo and Campus Veracruz) for financial support. Authors also wish to thank M.C. Juan Manuel Hernández Pérez for his assistance on the revision and formatting of this article.

\section{References}

Aidarov, I. P., \& Zavalin, A. A. (2015). Justification of complex land melioration (theory and practice). VNIIA Publ., Moscow, Russia.

Aidarov, I. P., Venitsianov, E. V., \& Radkovich, D. Ya. (2002). On the problem of environmental rehabilitation of river basins. Water Resources, 29(2), 219-229. https://doi.org/10.1023/A:1014917724193

Barmin, A. N., Iolin, M. M., \& Grigorenkova, E. I. (2012). The structure and dynamics of land use in the northern part of the Volga-Akhtuba floodplain. Geoecologiya, Geografiya y Globalnaya Energiya, 2(45), 174-179.

Baryshnikov, N. B. (1984). Morphology, hydrology and hydraulics of floodplains. Gidrometeoizdat Publ, Leningrad, Russia.

Chernikov, V. A., \& Cherekes, A. I. (Eds.). (2000). Agroecology. Kolos Publ., Moscow, Russia.

Gidroproyect. (1955). Characteristics of the hydrological regime of the Volga-Akhtuba floodplain. Materials of use of the Volga River downstream. Gidroproyect Publ., Moscow, Russia.

Government of the Astrakhan Region. (2010). The state of the program "Clean Water in Astrakhan region for 2010-2014 and up to 2017”. GAR Publ., Astrakhan, Russia.

Iolin, M. M., Sorokin, A. N., \& Starichkova, K. A. (2011). Assessment of dynamics of the Volga-Akhtuba floodplain vegetation in the Kapustin Yar district. Povolzhskiy Ecologicheskiy Zhurnal, 4, 431-441.

Korotaev, V. P., \& Ivanov, V. V. (2000). Channel deformations in the downstream of the Volga River. Vestnik $M G U$, Geografia, 5(3), 37-43.

Loginov, V. V., \& Gelashvili, D. B. (2016). Damage to aquatic biological resources of the reservoirs of the Volga-Kama cascade caused by hydroelectric power plants. Principy Ecologii, 4, 4-25. https://doi.org/ 10.15393/j1.art.2016.4681

Nikitina, O. (2015). Environmental flow and its implication for freshwater ecosystems. Environmental flows in the Amur basin. WWF-Russia Publ., Moscow, Russia. Retrieved April, 2017, from https://ehlm.unece.org/ download/attachments/32702467/Nikitina_EFlows_final_august.docx?version=1\&modificationDate=14409 $14124195 \&$ api $=\mathrm{v} 2$

Odum, E. P. (1983). Basic ecology (3rd ed.). Publ. Philadelphia: W.B. Saunders Comp., USA.

Palmeri, L., Barausse, A., \& Jorgensen, S. E. (2014). Ecological Processes Handbook. CRC Publ., London-New York.

Pegov, S. A., \& Khomyakov, P. M. (1991). Modelling of environmental systems. Gidrometeoizdat Publ., Leningrad, Russia.

Plyusnin, N. I. (1938). Soils of the Volga-Akhtuba floodplain. Cognition of alluvium and alluvial soils. Regional Publ., Stalingrad.

Ramenskiy, L. G., Tsatsenkin, I. A., \& Chizhikov, O. N. (1954). Ecological assessment of the forage lands by analysis of vegetation cover. Selhosgiz Publ., Moscow, Russia. 
Ratkovich, D. Ya. (2003). Actual problems of water supply. Nauka Publ., Moscow, Russia.

Richter, B. D., \& Thomas, G. A. (2007). Restoring environmental flows by modifying dam operations. Ecology and Society, 12(1), 1-9. https://doi.org/10.5751/ES-02014-120112

Riznichenko, G. Yu. (2010). Mathematical modeling in biology. NITS Publ. Moscow-Izhevsk, Russia. Retrieved from http://chembaby.com/wp-content/uploads/2015/12/Riznich_lectures_2010.pdf

Shevtsova, L. V., Aliev, K. A., \& Kuzko, O. A. (1998). Ecological state of the Dniestr River. Naukova Dumka Publ., Kiev, Ukraine.

Tockner, K., \& Stanford, J. A. (2002). Riverine floodplains: present state and future trends. Environmental Conservation, 29, 308-330. https://doi.org/10.1017/S037689290200022X

Voronina, V. P. (2009). Agroclimatic potential of pasture ecosystems of South-Western Caspian region under a changing climate (Abstract of Ph.D. thesis, Volgograd, Russia, RIC Publ.). Retrieved April, 2017, from http://www.dissercat.com/content/agroekologicheskii-potentsial-pastbishchnykh-ekosistem-severo-zapadno go-prikaspiya-v-usloviy

Warner, A. T., Bach, L. B., \& Hickey, J. T. (2014). Restoring environmental flows through adaptive reservoir management: planning, science, and implementation through the Sustainable Rivers Project. Hydrological Sciences Journal, 59(3-4), 770-785. https://doi.org/10.1080/02626667.2013.843777

WCD (World Commission on Dams). (2000). Dams and development. A new Framework for Decision-Making. The Report of the WCD. Earthscan Publications, London, UK. Retrieved April, 2017, from http://www.unep.org/dams/WCD/report/WCD_DAMS\%20report.pdf

White, G. F. (1989). In R. W. Kates \& I. Burton (Eds.), Geography, resources and environment. Univ. of Chicago Press, USA.

Yakovlev, S. V. (2014). Past, present and future of migratory fishes in the downstream of Volga River. Vestnik Volgogradskogo Otdeleniya Russkogo Geograficheskogo Obschestva, 9(141), 1-5.

Zhong, Y., \& Power, G. (1996). Environmental impacts of hydroelectric projects on fish resources in China. Regulated Rivers: Research and Management, 12, 81-98. https://doi.org/10.1002/(SICI)10991646(199601) $12: 1<81::$ AID-RRR378>3.0.CO;2-9

Zvolinskiy, V. P. (2016). Regulation of the Volga River hydrological regime-Way to rational environmental management. Modern trends in development of the agricultural complex of Salty Zaimische (pp. 3-12). FGBNU PNIIAZ Publ., Volgograd, Russia.

\section{Copyrights}

Copyright for this article is retained by the author(s), with first publication rights granted to the journal.

This is an open-access article distributed under the terms and conditions of the Creative Commons Attribution license (http://creativecommons.org/licenses/by/4.0/). 